\title{
Stratigraphic and palaeoenvironmental framework of the Early Permian sequence in the Salt Range, Pakistan
}

\author{
Shahid Ghazi ${ }^{1,2, *}$, Nigel P Mountney ${ }^{1}$, Aftab Ahmad Butt ${ }^{2}$ and Sadaf Sharif ${ }^{2}$ \\ ${ }^{1}$ School of Earth and Environment, University of Leeds, Leeds LS2 9JT, UK. \\ ${ }^{2}$ Institute of Geology, Punjab University, Lahore 54590, Pakistan. \\ *Corresponding author.e-mail: ghazigeo@yahoo.com
}

The Early Permian Gondwana regime succession of the Nilawahan Group is exposed only in the Salt Range of Pakistan. After a prolonged episode of non-deposition that spanned much of the Palaeozoic, the $350 \mathrm{~m}$ thick predominantly clastic sequence of the Nilawahan Group records a late glacial and post-glacial episode in which a range of glacio-fluvial, marine and fluvial environments evolved and accumulated. The Early Permian succession of the Salt Range has been classified into four formations, which together indicates a changing climatic regime during the Early Permian in the Salt Range region. The lower-most, Tobra Formation unconformably overlies a Cambrian sequence and is composed of tillite, diamictite and fresh water facies, which contain a floral assemblage (Gangamopteris and Glossopteris) that confirms an Asselian age. The Tobra Formation is overlain by marginal marine deposits of the Dandot Formation (Sakmarian), which contain an abundant brachiopods assemblage (Eurydesma and Conularia). Accumulation of the Dandot Formation was terminated by a regional sea-level fall and a change to the deposition of the fluvial deposits of the Warchha Sandstone (Artinskian). The Warchha Sandstone was deposited by high sinuosity meandering, avulsion prone river with well developed floodplains. This episode of fluvial sedimentation was terminated by a widespread marine transgression, as represented by the abrupt upward transition to the overlying shallow marine Sardhai Formation (Kungurian). The Early Permian Gondwana sequence represented by the Nilawahan Group is capped by predominantly shallow shelf carbonate deposits of the Tethyan realm. The sedimentologic and stratigraphic relationship of these four lithostratigraphic units in the Salt Range reveals a complex stratigraphic history for the Early Permian, which is mainly controlled by eustatic sea-level change due to climatic variation associated with climatic amelioration at the end of the major Gondwana glacial episode, and the gradual regional northward drift to a lower latitude of the Indian plate.

\section{Introduction}

The Salt Range region of Pakistan has long been the focus of geological study because of its varied geology that ranges from Precambrian to Recent in age (Gee 1989; Ghazi 2009), yet the detailed sedimentology of the succession and its palaeoenvironmental significance remain relatively poorly understood. The Salt Range of Pakistan forms southernmost part of the Sub-Himalayan Mountains, which stretch for more than $180 \mathrm{~km}$ east-west between the Jehlum and Indus rivers, along the southern margin of the Potwar Basin (figure 1). Within the Salt Range, a thick sedimentary cover, consisting of Precambrian to recent deposits (figure 2), unconformably overlies low-grade metamorphic and igneous rocks (Gee 1989). The initiation of Permian sedimentation in Pakistan and

Keywords. Early Permian; palaeoenvironment; Salt Range; Pakistan. 
a

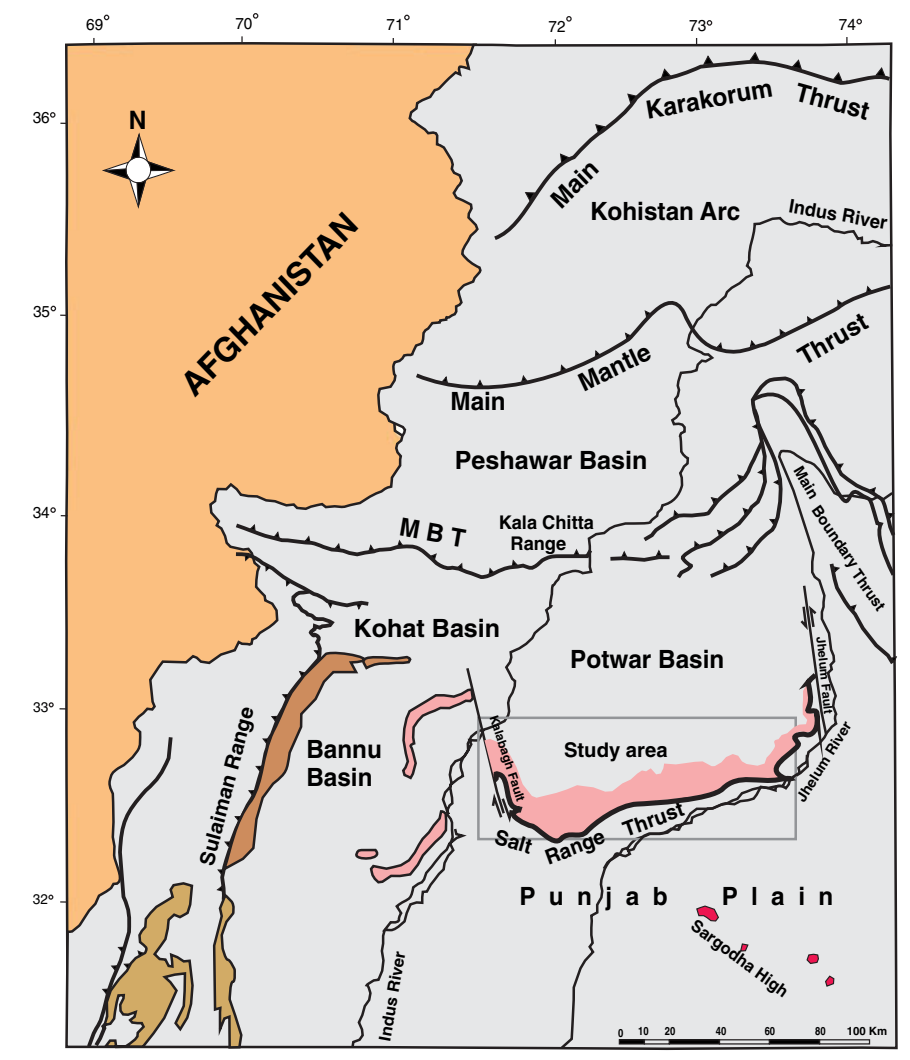

b

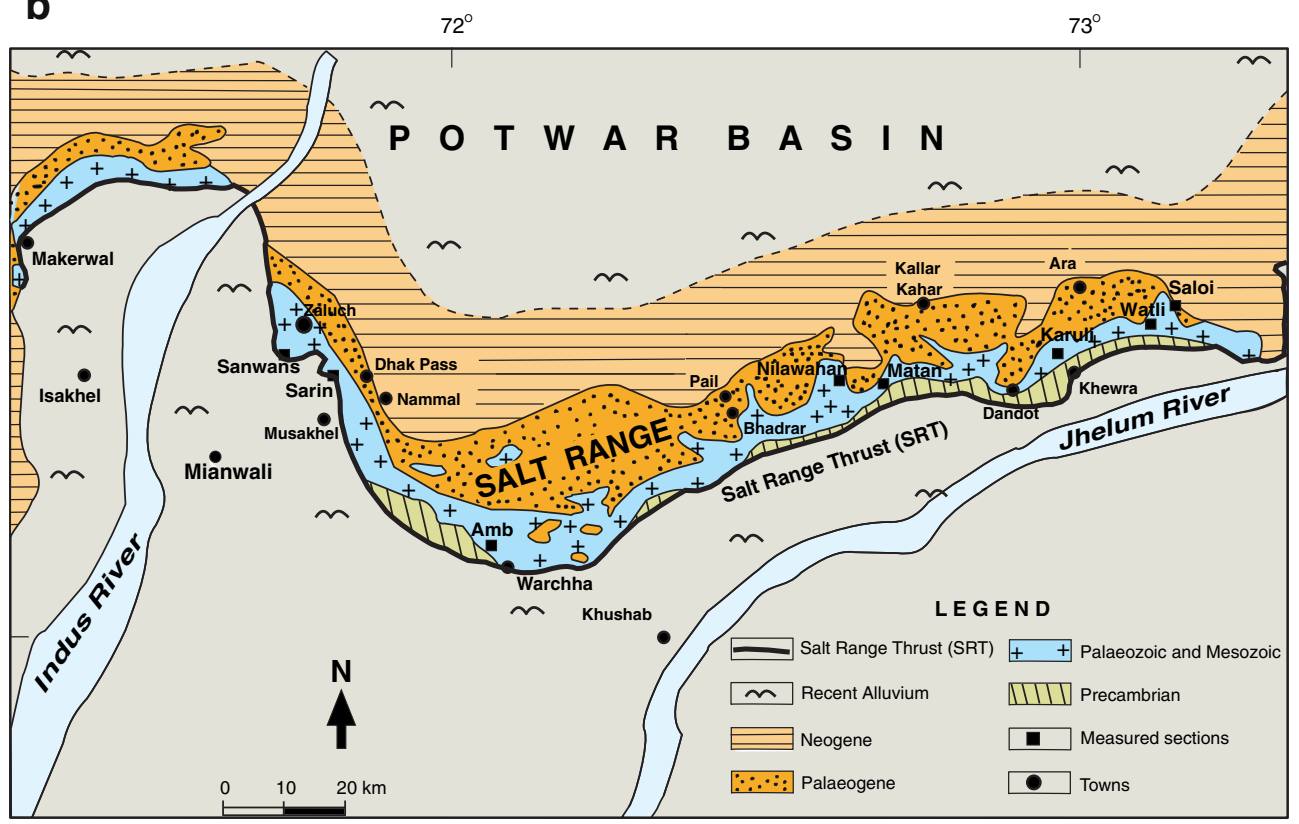

Figure 1. Location map of the Salt Range. (a) Generalized tectonic map of northern Pakistan, showing location of the Salt Range and (b) outcrop belt of the Early Permian succession in the Salt Range of Pakistan showing the location of eight measured sections, which form the principal study localities discussed in this paper.

India marked the end of long phase non-deposition that had prevailed across much of the Indian subcontinent since the Late Proterozoic (Dasgupta 2006). The Permian stratigraphy of the Salt Range is divisible into the Early Permian Nilawahan Group and the Late Permian Zaluch Group. These successions are of particular interest to sedimentologists and palaeontologists alike because the Gondwanan clastic sediments of Early Permian age are overlain by the highly fossiliferous Late Permian carbonate deposits of the Tethyan realm. Thus, the two principal groups reflect markedly different geological and palaeogeographical settings. 


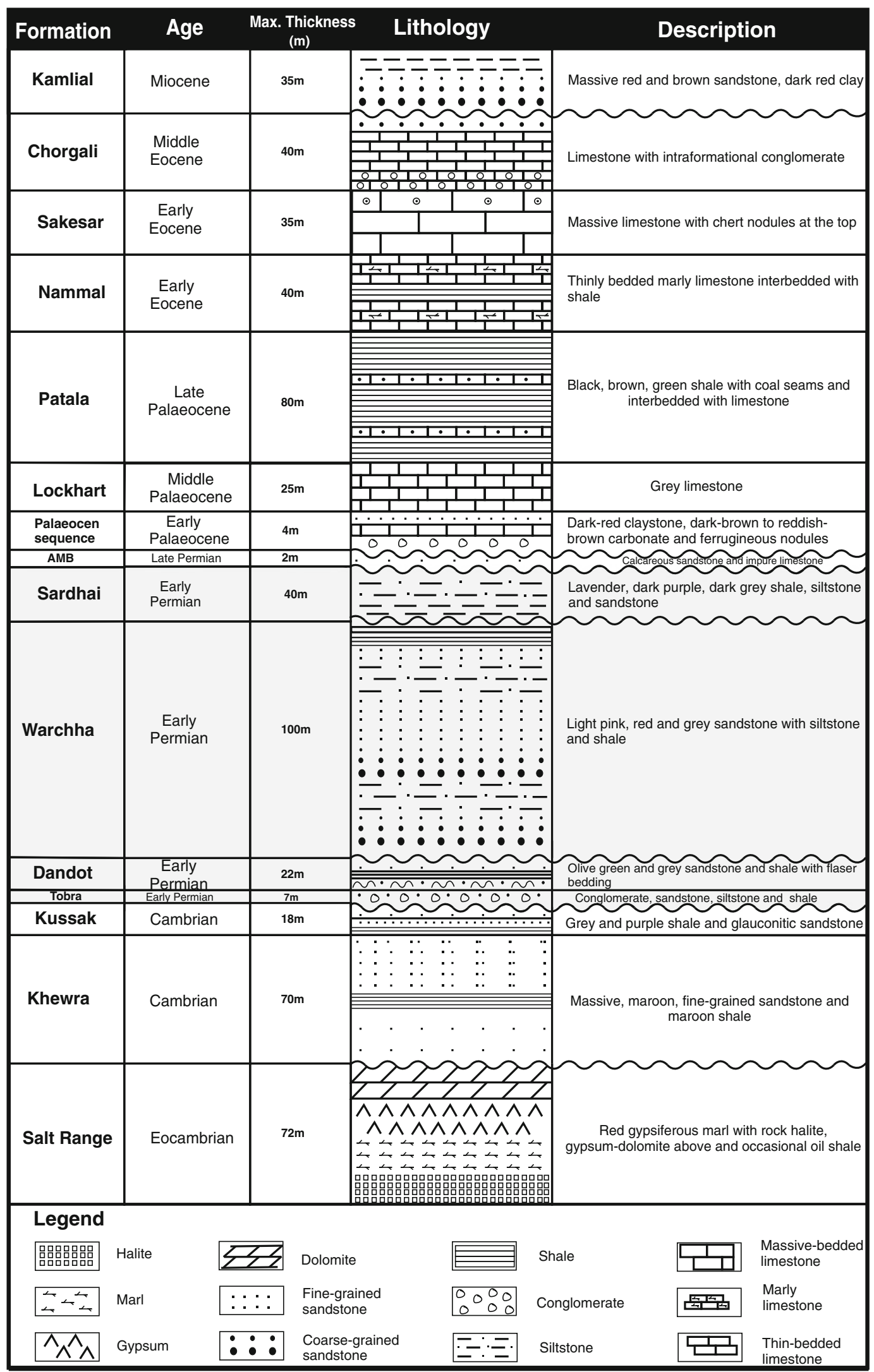

Figure 2. Summary of the principal stratigraphic units exposed in the Nilawahan Gorge area of the central Salt Range, Pakistan. 
The original and still widely accepted stratigraphic framework for the Early Permian in the Salt Range classified the Nilawahan Group succession into four units: the Tobra Formation (Asselian), the Dandot Formation (Sakmarian), the Warchha Sandstone (Artinskian) and the Sardhai Formation (Kungurian) (Ghazi 2009). The ages assigned to these formations are in accordance with the Stratigraphic Commission and the Geological Time Scale (Gradstein et al. 2004). Each lithostratigraphic unit is interpreted to have accumulated under a distinct climatic regime that progressively changed throughout the Early Permian in the Salt Range region from very cold to cold (the Tobra Formation), to cold-cool (the Dandot Formation), to cool-warm (the Warchha Sandstone), to warm-hot (the Sardhai Formation) (Singh 1987; Veevers and Tewari 1995).

The aims of this paper are:

- to review the Early Permian stratigraphic nomenclature of the Salt Range,

- to demonstrate the importance of the Early Permian succession of the Salt Range in terms of its significance for assisting in the erection of a global palaeogeographic model for the Permian period, and

- to correlate the Early Permian successions of the Salt Range with other parts of the Gondwanaland sedimentary sequence.

\section{Permian rocks of the Salt Range}

The Salt Range of Pakistan is home to one of the best-known Permian sequences in the world (Waterhouse 1970; Singh 1987). These Permian strata, which were deposited on the continental margin of Indo-Pakistani Plate, are exposed throughout much of the Salt Range (Wardlaw and Pogue 1995). Pascoe (1959) first noted that the Permian sediments unconformably overlie the Cambrian sequence in the Salt Range and referred them as the Early Permian age Shahpur System, which were sub-divided into Nilawahan Series and Productus Limestone Series. The Permian succession is represented by a $700 \mathrm{~m}$-thick accumulation of strata, which is readily sub-divided into two major units of roughly equal thickness (Kummel and Teichert 1970), each of which represents accumulation under markedly different depositional conditions (figure 1). The Early Permian sequence is assigned to the Nilawahan Group, which belongs to Gondwana regime and records sedimentation under a range of continental and marginal-toshallow marine setting (figure 1; Gee 1989; Ghazi 2009). The Late Permian sequence is assigned to the Zaluch Group, which belongs to the Tethyan regime and is entirely marine in origin (Kummel and Teichert 1970; Wardlaw and Pogue 1995).

The four principal sub-divisions of the Nilawahan Group (the Tobra, Dandot, Warchha and

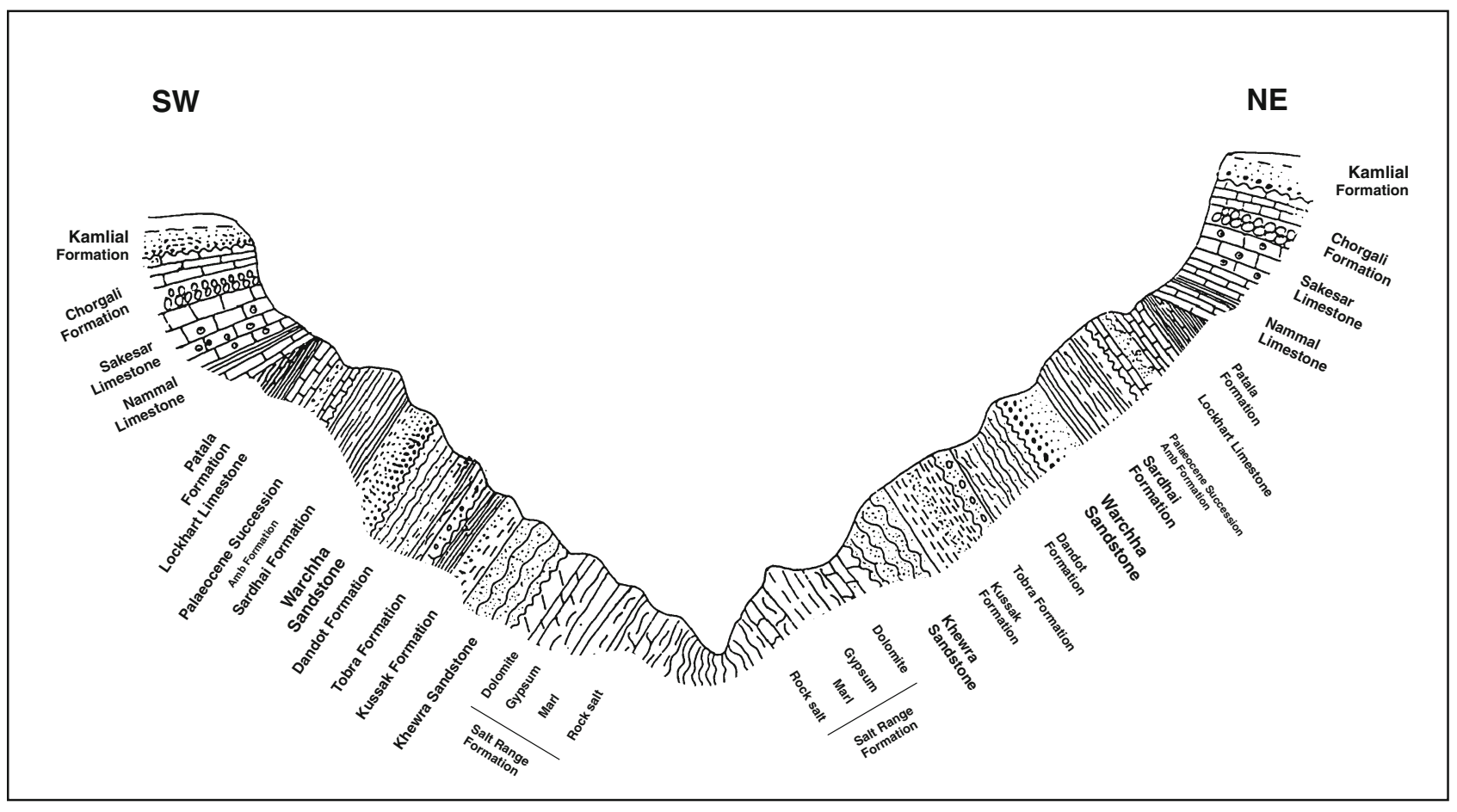

Figure 3. Sketch cross-section depicting the arrangement of Precambrian to Miocene stratigraphic units within the Nilawahan Gorge (not to scale). 
Sardhai formations) are preserved in several outcrops distributed along the Salt Range Thrust (SRT), a major tectonic unit that defines the frontal limit of the Salt Range uplift (figure 1). Exposure is widespread, though much is highly tectonically disturbed. However, well exposed laterally- and vertically-continuous sections exist in the main gorges that cut through the range and worthwhile exposures in several road cuttings (figure 1). This allows broad correlation of the main lithostratigraphic units across the Salt Range and a basic reconstruction of the principal palaeodepositional environments represented (figures 2 and 3). The succeeding Zaluch Group in the Salt Range is a well-exposed succession of exclusively shallow marine to intertidal deposits and is composed of the Amb, Wargal and Chhidru formations (Kummel and Teichert 1970; Fatmi 1973; Shah 1977; Gee 1980, 1989; Mertmann 2003). The lower contact of the Amb Formation is unconformable with the Sardhai Formation and the upper contact of the Chhidru Formation is unconformable with the overlying Mianwali Formation of Triassic age (figure 2; Kummel and Teichert 1970; Gee 1980; Mertmann 2003).

\section{Lithostratigraphic analysis of the Early Permian succession of the Salt Range}

The four Early Permian lithostratigraphic units of the Salt Range developed during four stages: the
Asselian, Sakmarian, Artinskian and Kungurian (Pascoe 1959; Wensink 1975; Veevers and Tewari 1995). These units are now known to be each bounded by diachronous surfaces (Ghazi 2009), the nature of the diachronous relationships being demonstrable by the occurrence of distinctive biostratigraphic and lithostratigraphic characteristics (figure 4). Based on biostratigraphy and correlative stratigraphic position (figure 4) the age of the Tobra Formation is largely Asselian, the Dandot Formation is largely Sakmarian, the Warchha Sandstone is largely Artinskian and the Sardhai Formation is largely Kungurian (e.g., Krishnan 1960; Balme 1970; Ghosh and Mitra 1970; Shah and Sastry 1973; Singh 1987; Veevers and Tewari 1995; Wardlaw and Pogue 1995). The four lithostratigraphic units of the Early Permian Nilawahan Group of the Salt Range record sedimentation within a variety of depositional environments that range from glacio-fluvial to shallow marine in the Tobra Formation, marginal to shallow marine in the Dandot Formation, meandering fluvial to marginal marine in the Warchha Sandstone and open shallow marine in the Sardhai Formation (figures 4 and 5).

\subsection{Tobra Formation}

The Tobra Formation is the oldest lithostratigraphic unit of the Early Permian Nilawahan Group (figures 4 and 5). The Tobra Formation was

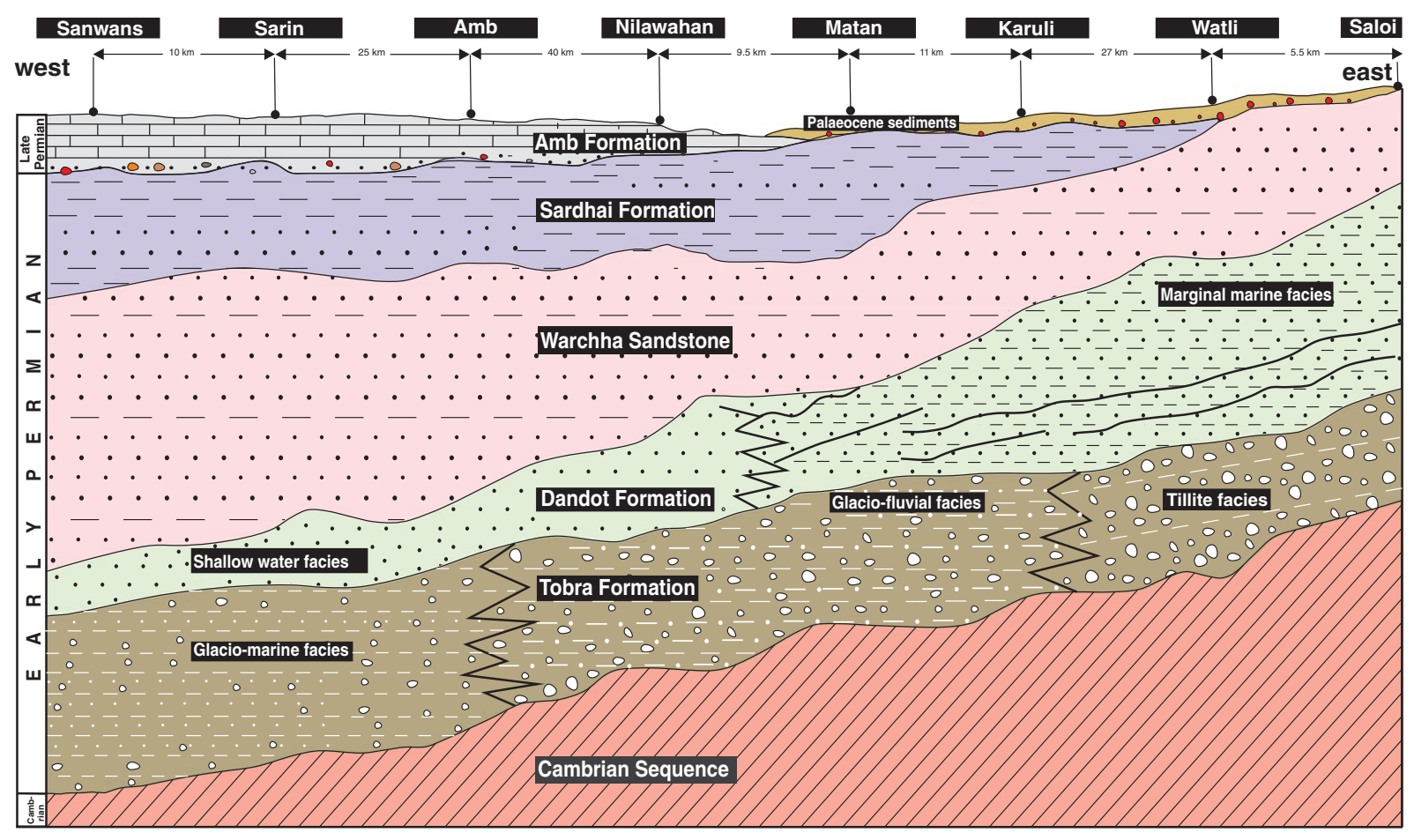

Figure 4. Regional stratigraphic framework of the Early Permian Nilawahan Group in the Salt Range region. 


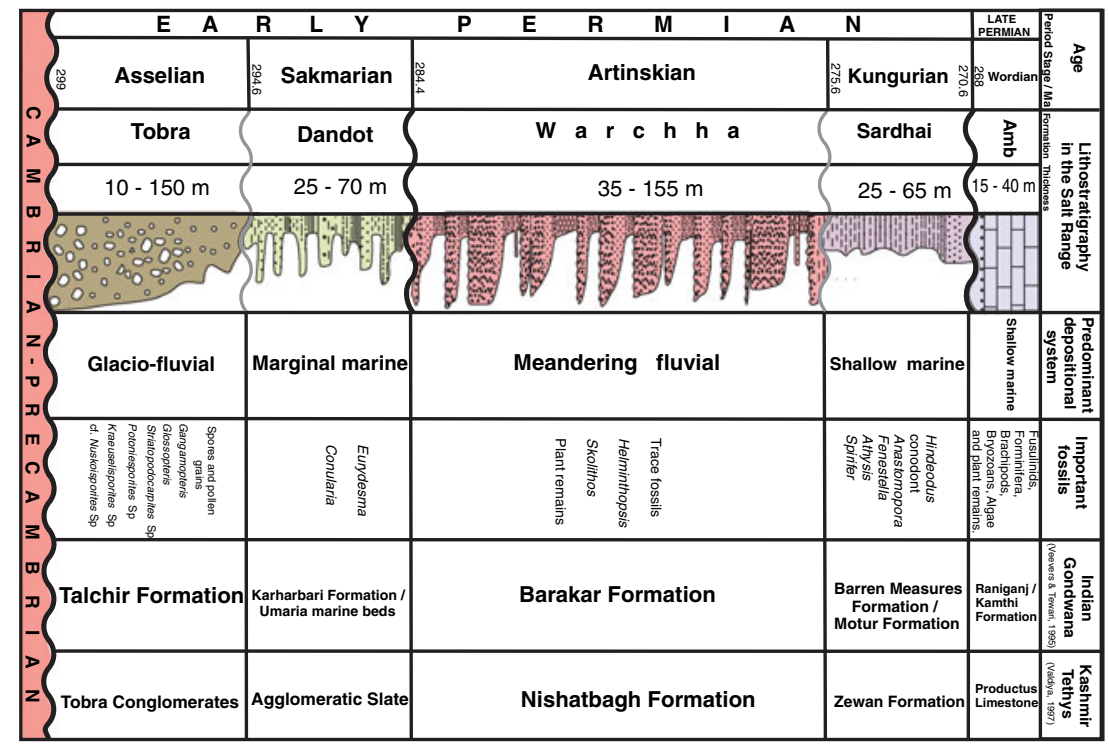

Figure 5. Correlation of the Early Permian formations of the Salt Range with the Gondwanan Basins of India and the marine Tethys deposits. Data are compiled from Noetling (1901), Fatmi (1973), Singh (1987), Veevers and Tewari (1995), Wardlaw and Pogue (1995), Valdiya (1997), Mertmann (2003) and Gradstein et al. (2004).

originally referred to as the Talchir Boulder Beds by Noetling (1901), the name having been taken from the Talchir Group of Blanford et al. (1856) after its occurrence in Talchir State (Cuttack District), Orissa, India (Krishnan 1960). Subsequently, the Stratigraphic Committee of Pakistan formalized the name of the unit as the Tobra Formation, after the village of Tobra in the eastern Salt Range Pakistan (Fatmi 1973) and this is now considered as type locality of the formation. The Tobra Formation was the first unit to accumulate and be preserved in response to the Carboniferous-Permian glaciations that influenced the subcontinent during the Early Permian times. The unit is widespread in the Salt and Trans-Indus ranges and its thickness varies from $10 \mathrm{~m}$ in the Khewra area of the eastern Salt Range to $150 \mathrm{~m}$ in the Sarin and Zaluch areas of the western Salt Range (figures 1 and 4).

The Tobra Formation is predominantly composed of greenish-grey to dark-grey, brown and black-coloured conglomerate and sandstone (figure $6 \mathrm{a}-\mathrm{b})$. Pebble to boulder-sized clasts are common and are mainly composed of pink granite, gneiss and quartzite in a poorly sorted sandy and olive-green-coloured silty and mudy matrix (figure $6 \mathrm{a}-\mathrm{b})$. The average size of clasts measured at the Watli, Karuli, Nilawahan, Sarin and Sanwans area is $0.1-0.15 \mathrm{~m}$ in diameter. However, rarely larger clasts up to $0.35 \mathrm{~m}$ in diameter have been observed elsewhere (figure 6b). The surfaces of the majority of clasts are generally polished and striated.

Three lithofacies were identified by Teichert (1967) in the Tobra Formation (figure 4). A tillite facies is restricted to the eastern Salt Range. A fresh water facies of alternating siltstone and shale and containing a spore flora and a few scattered boulders in its basal parts (glacio-fluvial facies) is located predominantly in the central Salt Range. A mixed facies of diamictite, sandstone and boulder beds of marine and estuarine origin (glacio-marine

Figure 6. (a) Example of matrix-rich conglomeratic tillite deposits in the upper part of the Tobra Formation in the Watli area, eastern Salt Range. Note the varied composition and size of the clasts (hammer is $0.3 \mathrm{~m} \mathrm{long}$ ). (b) Example of stratified glacio-marine diamictite (shale with large dropstone of pink granite) in the upper part of the Tobra Formation in the Sarin area, western Salt Range (hammer is $0.3 \mathrm{~m} \mathrm{long}$ ). (c) The erosional contact between the marine shale of the Dandot Formation and an overlying fluvial channel at the base of the Warchha Sandstone, Amb area, central Salt Range (hammer is $0.3 \mathrm{~m}$ long). (d) Petrified wood in the upper part of the Dandot Formation in the Saloi area, eastern Salt Range (pencil is $0.154 \mathrm{~m}$ long). (e) The contacts between fine-grained marine sandstone facies of the Dandot Formation with underlying glacio-marine facies of the Tobra Formation and overlying fluvial channel of the Warchha Sandstone in the Sanwans area, western Salt Range. (f) Photograph showing upper erosional contact of the Warchha Sandstone with overlying red-coloured Palaeocene sequence in the Saloi area, eastern Salt Range (hammer is $0.3 \mathrm{~m} \mathrm{long).} \mathrm{(g)} \mathrm{Photograph}$ showing the Sardhai Formation unconformably overlain by Palaeocene Strata in the Matan area, central Salt Range. (h) Photograph showing the Sardhai Formation overlying the Warchha Sandstone with an unconformable relationship and itself overlain by the Amb Formation of the Zaluch Group in the Sarin area, western Salt Range. 

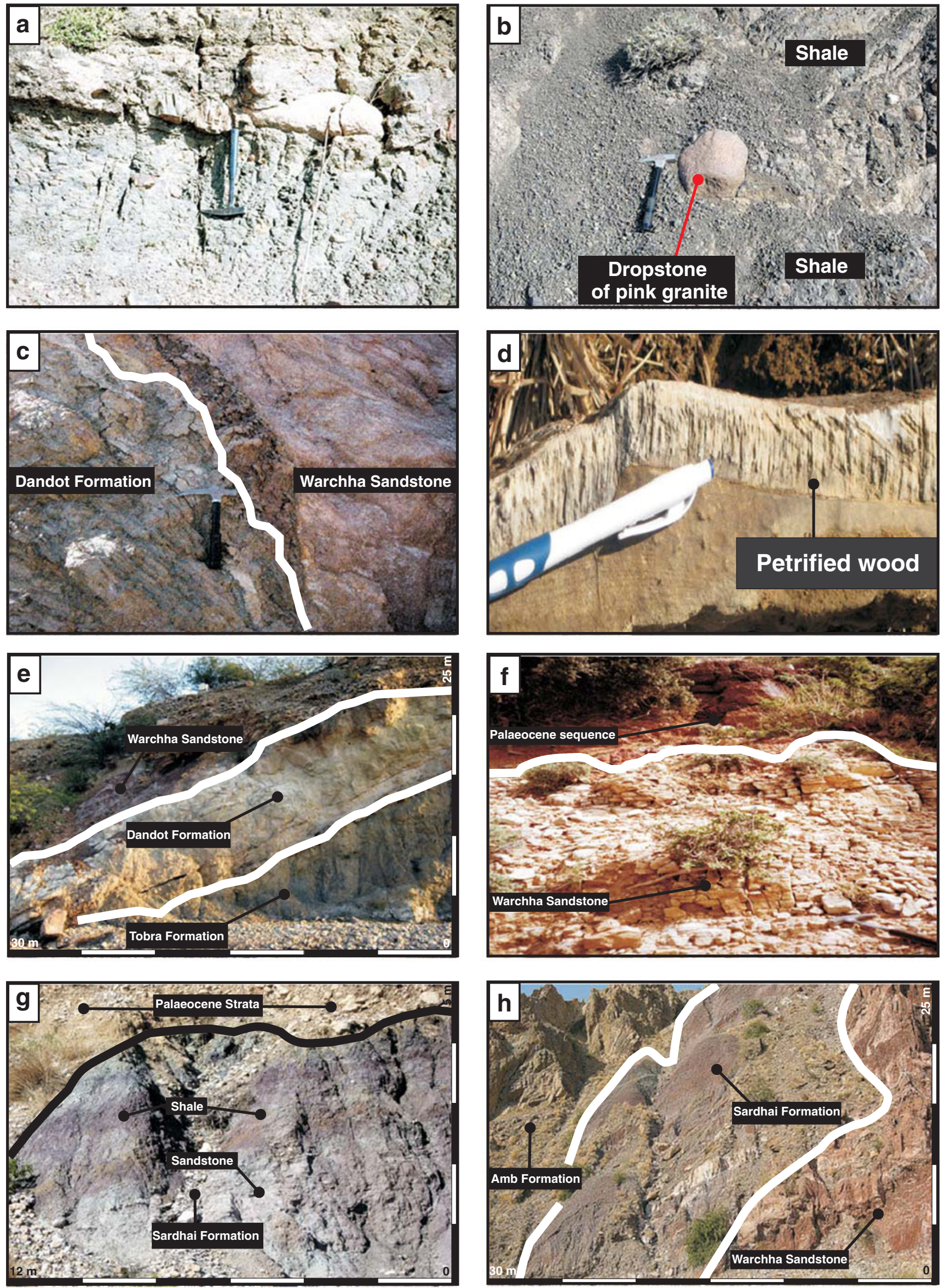
facies) is located predominantly in the western Salt Range.

Based on the occurrence of age-diagnostic plant fossils including Gangamopteris, Glossopteris and Striatopodocarpites sp., an Early Permian (Asselian) age has been assigned to the Tobra Formation (Balme, in Teichert 1967; Shah and Sastry 1973; Gee 1989). The basal contact of the formation with the underlying Cambrian sequence is marked by an angular unconformity (Lillie et al. 1987) and demonstrates a major episode of non-deposition, uplift and erosion that resulted in the absence of the entire Ordovician to Carboniferous record. The upper contact is gradational with the overlying Dandot Formation and indicates a gradual temporal change in both lithofacies and climate regime.

\subsection{Dandot Formation}

The Dandot Formation is now formally recognized by the Stratigraphic Committee of Pakistan (Fatmi 1973), and is the official name for a unit that was previously known as the Conularia Beds (Wynne 1878), Conularia-Eurydesma Beds (Waagen 1878) and the 'Dandot Group' (Noetling 1901). The unit is $50 \mathrm{~m}$ thick at its type locality in the Dandot area of the eastern Salt Range (Fatmi 1973; Shah 1977), though is well developed throughout the Salt Range (figures 4 and 5), deposit erroneous claim by some workers (e.g., Fatmi 1973; Shah 1977) that it absent in the western Salt Range. The Dandot Formation exhibits a lateral variation in lithofacies (figure 4) and gradually changes from strata of marginal marine origin to strata of shallow marine origin in the western Salt Range (Noetling 1901). The maximum exposed thickness of this formation is $70 \mathrm{~m}$ and is recorded in the Sarin and Sanwans areas in the western Salt Range.

The formation in the eastern Salt Range is mainly composed of alternating laminated fine-grained sandstone, claystone and shale units. The sandstone is generally micaceous, greenish-grey, lightbrown and olive-green in colour, whereas the shales are dark-green to dark-grey in colour (figure 6c). In the Saloi area, large pieces of petrified wood (5-10 $\mathrm{m}$ long and 0.6 to $0.12 \mathrm{~m}$ thick) have been observed at the top of the formation (figure $6 \mathrm{~d}$ ), which was previously wrongly described by Butt et al. (1994) as a vitric flow or volcanic glass bed. Thin beds of black shale (1-2 m thick) are recorded at a few places. In the Karuli, Matan and Nilawahan areas of the central Salt Range thin sandstone beds about $20-30 \mathrm{~mm}$ thick are interbedded in an otherwise shale-dominated succession and these are predominantly restricted to the lower part of the formation. The upper part of the formation is composed of alternately laminated micaceous finegrained siltstone and claystone and shale beds that are extensively burrowed.

The Dandot Formation is generally composed of thick, dark-coloured massive mudstone and fineto medium-grained sandstone in its lower parts in the western Salt Range, whereas, in its upper parts the unit is composed of interbedded, light-brown or dark-grey, micaceous, fine-grained sandstone and siltstone. The top-most part of the Dandot Formation exhibits thin coal seams in the Sarin area of the western Salt Range.

Flaser, lenticular and wavy-bedding, and ripple cross-lamination are abundant in the sandstone beds of the Dandot Formation. Some sandstone beds show bituminous staining in the lower and middle parts of the formation. Additionally, the interbedded, fine-grained sandstone, siltstone and shale units are rich in glauconite in places. An abundant and varied of faunal assemblage has been reported from the Dandot Formation, including Eurydesma, Conularia, Discina, Martiniopsis, Chonetes, Neochonetes (Waagen 1883; Reed 1944; Waterhouse 1970; Fatmi 1973). Pascoe (1959) and Krishnan (1960) reported marine bivalves from eastern Salt Range belonging to genus Eurydesma and other fossils including Eurydesma cardatum, E. hobartense, E. punjabicum, E. Subovatum, Pterinea cf. lata, Nucula pidhensis, Aviculopecten sp., Astartila cf. ovalis, Cardiomorpha penguis (Brachiopod) Dielasma dadanense; (Bryozoa) Fenestella fossula.

The gradational, transitional nature of the change from the underlying Tobra to the overlying Dandot Formation implies a gradual but significant regional rise in relative sea-level and a regionwide transgression of the Tethys Sea, probably in response to deglaciation across many parts of the Gondwanaland at this time (Ahmad 1970; Shah and Sastry 1973; Dickins 1977, 1985; Dasgupta 2006). The upper contact of the Dandot Formation with the overlying Warchha Sandstone is unconformable (figure 6c) and is characterized by an abrupt change in lithology and sedimentary style.

\subsection{Warchha Sandstone}

The name Warchha Sandstone, which was proposed by Hussain (1967), has now been formally adopted by the Stratigraphic Committee of Pakistan (Fatmi 1973). Warchha Sandstone refers to the speckled sandstone of Waagen (1878), which formed the lower part of the Warchha Group of Noetling (1901). The 'Warchha Gorge' in the central Salt Range was proposed as the type locality of the Warchha Sandstone, though no coordinates or grid references were given (Fatmi 1973; Shah 
1977). However, in more than five years of detailed field work in the vicinity of the Warchha Gorge and in the surrounding area, the principal author has not been able to identify a representative complete outcrop-section of the Warchha Sandstone. Therefore, based on its well exposed occurrence and lateral continuity of outcrop, the Matan $\left(72^{\circ} 41^{\prime} 38^{\prime \prime} \mathrm{E}, 32^{\circ} 39^{\prime} 46^{\prime \prime} \mathrm{N}\right)$ area and Karuli $\left(72^{\circ} 41^{\prime} 32^{\prime \prime} \mathrm{E}, 32^{\circ} 37^{\prime} 40^{\prime \prime} \mathrm{N}\right)$ areas in the central Salt Range are herein proposed as the type locality and reference section for the Warchha Sandstone (figures 1 and 4).

The Warchha Sandstone is exposed throughout the Salt Range and its thickness increases systematically from the east $(30 \mathrm{~m})$ to west $(155 \mathrm{~m})$ of the outcrop belt (figure 4). The reduced thickness of the Warchha Sandstone in the eastern Salt Range can be related to the gradual continuous uplift of the eastern Salt Range (cf. Gee 1989). The succession is composed of light-pink, red, reddish-brown and white-coloured fine- to coarse-grained sandstone, which is conglomeratic in places and has interbeds of siltstone and claystone. It is characteristically speckled in places. Several fining-upward cycles are recognised within the formation and these are composed of conglomerate and cross-bedded sandstone in their basal part and bioturbated siltstone and claystone/ mudstone in their upper part (Ghazi 2005, 2009; Ghazi and Mountney 2009). Complete examples of such cycles are characterised by seven lithofacies that occur in ascending order as stratified gravely sandstone (Gt), coarse-grained trough cross-bedded sandstone (St), medium- to coarsegrained planar cross-bedded sandstone (Sp), ripple cross-laminated sandstone $(\mathrm{Sr})$, very fine- to medium-grained sandstone with flat-bedding (Sh), parallel laminated siltstone and claystone $(\mathrm{Fl})$ and massive claystone/mudstone (Fm). Trace fossils including Helminthopsis and Skolithos are observed at the top of the Warchha Sandstone.

Clasts are mainly of plutonic and low-grade metamorphic origin, with an additional minor sedimentary component (Ghazi and Mountney 2011). Textural properties of the sandstone are fine- to coarse-grained, poorly- to moderately-sorted, subangular to sub-rounded and generally with a loose packing. Compositionally, the Warchha Sandstone is dominantly a sub-arkose to arkose in nature (Ghazi and Mountney 2011). A broad range of sedimentary structures are recognised, including different forms of bedding, cross bedding, ripple forms, ripple stratification, channels, flute casts, load casts, desiccation cracks, rain imprints, conein-cone structures, a variety of concretions and bioturbation. The occurrence and abundance of these structures varies in a systematic manner throughout the vertical thickness of the succession. The nature of sedimentary structures in the Warchha Sandstone succession is closely analogous to the modern fluvial deposits (Ghazi 2009). The gross lithology, sedimentary structures and cyclic nature of the Warchha Sandstone reveal a fluvial style of deposition. Most of the Warchha Sandstone beds were formed by continuous or intermittent current flow within migrating river channels, in which bodies of standing water were rare (Ghazi 2009).

The Warchha Sandstone unconformably overlies the marginal marine Dandot Formation of Early Permian (Sakmarian) age (figure 6e). In the eastern Salt Range, the Warchha Sandstone is unconformably overlain by shallow marine deposits of Palaeocene age (figure 6f), and in rest of the Salt Range it is unconformably overlain by the Sardhai Formation of Early Permian (Kungurian) age, which forms the uppermost unit in the Nilawahan Group. Balme (1970) and Wardlaw and Pogue (1995) assigned an Early Permian (Artinskian) age for the Warchha Sandstone on the basis of pollen spores.

\subsection{Sardhai Formation}

The Sardhai Formation represents the uppermost stratigraphic unit of the Nilawahan Group. The name Sardhai Formation, which was taken from the Sardhai Gorge of the central Salt Range, was proposed by Hussain (1967) and this locality has now been accepted by the Stratigraphic Committee of Pakistan as the type section (Fatmi 1973). The unit was previously referred as 'lavender clay' by Waagen (1878) and the upper part of 'Warchha Group' by Noetling (1901). The Sardhai Formation is well-developed in the central and western ranges; but is absent in the easternmost part. It is $42 \mathrm{~m}$ thick at its type locality but its thickness varies from 25 to $65 \mathrm{~m}$ overall. The formation generally forms poorly exposed slopes.

The Sardhai Formation consists principally of light- to medium-grey, greenish-grey and lavendercoloured silty-shale with thin interbeds of siltstone and fine-grained glauconitic sandstone. Based on field observations, the Sardhai Formation in the Salt Range can be divided into three parts on the basis of lithology (figures 4 and 5). The lower part of the formation contains reddish-brown, lavender and dark-grey shale interbedded with greenish-grey to grey-coloured, fine-grained sandstone with occasional siltstone interbeds. The middle part is mainly composed of lavender and greenish-grey claystone interbedded with very fine-grained light-grey sandstone. The upper part is predominantly composed of lavender, blueish to greenish-grey coloured shale with thin bedded greenish-grey siltstone. The upper parts 
of the formation are generally sandier in the central Salt Range, whereas in western Salt Range the lower part is sandier. In many places the shale is carbonaceous and contains some copper minerals including chalcopyrite (Qureshi 1980). Minor chert and gypsum with occasional calcareous beds occur in the upper part of the formation (Fatmi 1973; Shah 1977). The lithology of the unit changes laterally to black shale and brown-coloured argillaceous limestone in Trans-Indus Ranges (Fatmi 1973).

Hussain (1967) reported a variety of fauna including Anastomopora, Fenestella, Athyrsis and Spirifer from the Sardhai Formation. Bryozoans and Brachiopods are recorded in limestone beds from Trans-Indus Ranges (Fatmi 1973; Qureshi 1980). Alam et al. (1987) have identified fish debris, teeth and an environment-diagnostic Hindeodus conodont from the Jhang-Well core sample, which was drilled about $150 \mathrm{~km}$ south of the Salt Range in the Punjab Plain. The absence or only limited development of the Sardhai Formation in the eastern Salt Range area can be related to its removal following the uplift due to a Pre-Palaeocene orogeny (Gee 1989). The upper part of the Sardhai Formation was completely eroded across the entire area during uplift at this time. The lower contact of this formation with the Warchha Sandstone is erosional. The upper contact with the Palaeocene strata in the eastern Salt Range and with the Amb Formation of Zaluch Group in western Salt Range is unconformable (figure $6 \mathrm{~g}-\mathrm{h}$ ).

\section{Depositional setting of the Early Permian succession of the Salt Range}

The region of the Salt Range at the margin of Tethys received sediments during the Early Permian time after a long post-Cambrian hiatus similarly as the other Gondwana Basins of Peninsular India (Mukhopadhyay et al. 2010). Initial sedimentation in the Salt Range region took place due to melting of ice (Mukhopadhyay et al. 2010) in the form of the Tobra Formation. The weathering style and composition of the conglomeratic clasts in the Tobra Formation have been interpreted to reflect a glacial mechanism for transportation and deposition (Pascoe 1959; Teichert 1967; Gee 1989). The Tobra Formation contains clasts dominantly of igneous and metamorphic rocks sourced from the Aravalli and Malani ranges that lie about $600 \mathrm{~km}$ to the south of the Salt Range (Teichert 1967; Shah and Sastry 1973). The matrix has the same composition and origin characteristics as the large clasts and likely reflects high rates of abrasion through the grinding effects of glacial action in the source area and along the sediment transport path. The presence of glacially-polished surfaces, striations and whaleback knobs throughout much of the outcrop in the Salt Range are indicative of ice sheet movement over the older bedrock (Haldorsen et al. 2001). Melting of ice sheets resulted in glacio-fluvial conglomerate and pebbly sandstone deposits (e.g., Angiolini et al. 2004). All the above characteristics indicate that the environment of deposition of the Tobra Formation in the Salt Range area was mainly glacio-fluvial (Teichert 1967; Fatmi 1973; Gee 1989).

During the Sakmaria, deglaciation caused rise in sea-level and seawater transgressed towards Salt Range region, which is manifested by the occurrence of marine fauna like Eurydesma in the Dandot Formation (e.g., Bangert et al. 1999; Mukhopadhyay et al. 2010). Lithologically, the interbedded, fine-grained sandstone, siltstone and shale units are rich in glauconite along with abundant flaser, lenticular and wavy-bedding, and ripple cross-lamination in the sandstone beds of the Dandot Formation. The lithological and palaeontological characteristics indicate a marine environment for the deposition of the Dandot Formation, with cool water temperatures $\left(<6^{\circ} \mathrm{C}\right.$; Bischoff et al. 1993; Singh 1987; Veevers and Tewari 1995; Fielding et al. 2006). Overall, the Dandot Formation was deposited in a range of shallow marine to marginal marine environments.

After the deposition of the Dandot Formation, near shore environment prevailed in the Salt Range region with the advent of fluvial environment (Mukhopadhyay et al. 2010). The Warchha Sandstone is primarily fluviatile in origin (Wardlaw and Pogue 1995; Ghazi et al. 2004; Ghazi and Mountney 2009, 2011). Detailed palaeocurrent analysis (Ghazi 2009) demonstrates that the succession represents the depositional product of a high-sinuosity system with an overall dominant flow direction to the north-northwest (Ghazi 2009; Ghazi and Mountney 2011). Petrographic analysis indicates the provenance of the Warchha Sandstone to the Aravalli Range to the southeast and the Malani Range to the south of the Salt Range, suggesting northward transport across a broad alluvial plain towards the margin of the Tethys Ocean in the north (Ghazi et al. 2004; Ghazi and Mountney 2011). Presence of trace fossils including Helminthopsis and Skolithos in the Warchha Sandstone indicate a marine influence at the top of the unit (cf. Bjerstedt 1988; Ranger and Pemberton 1997; Stow 2005; Collinson et al. 2006; Fielding et al. 2006).

During Late Artinskian to Early Kungurian time another marine transgression started under arid to semiarid conditions in the Salt Range region. The lithologically dominant light- to medium-grey, 
greenish-grey and lavender-coloured shale with thin interbeds of siltstone and fine-grained glauconitic sandstone deposits of the Sardhai Formation was deposited in warm-hot climatic conditions (Singh 1987; Veevers and Tewari 1995). The presence of chert along with gypsum, chalcopyrite and mineral glauconite are all evidence for the prevalence of marine environmental conditions during deposition of the Sardhai Formation (Wardlaw and Pogue 1995).

\section{Early Permian sequence development in Salt Range}

Accumulation of the Permian sequence in the Salt Range commenced after a major break in deposition that encompassed the time interval from the Middle Cambrian until the end of the Carboniferous (Kummel and Teichert 1970; Gee 1989). Initial accumulation of the Early Permian Nilawahan Group occurred under the influence of a series of major glacial episodes that affected large areas of Gondwanaland throughout much of the Carboniferous-Permian periods (Kummel and Teichert 1970; Veevers and Tewari 1995). However, the later stages of the accumulation of the Nilawahan Group appear to have been controlled by the effects of an increasingly warmer climate regime (Singh 1987). The occurrence of exclusively marine successions both below (the Dandot Formation) and above (the Sardhai Formation) the continental deposits of the Warchha Sandstone indicate a major regression and subsequent marine transgression associated with the lowering and rising of the Tethys sea level during Early Permian times (Ahmad 1970; Shah and Sastry 1973; Singh 1987; Ghazi 2009). Two regional sea-level changes are evident from the facies and stratigraphic relationships of the Early Permian sequence in the Salt Range of Pakistan and also in India (Shah and Sastry 1973). Evidence for the first prominent sealevel change is present in the Early Permian (Sakmarian) Dandot Formation (Dickins 1977, 1985; Singh 1987). The relationship between upper part of the Tobra Formation and the overlying Dandot Formation is transitional (Teichert 1967) and records a progressive sea-level rise through the upper part of the Tobra Formation into the lower part of the overlying Dandot Formation, which is correlated with the globally identified Eurydesma transgression (Visser 1997b) that is related to both the melting of Gondwanan ice caps and eustatic rise in sea-level (Dickins 1977, 1985). This global event can be recognised in many parts of the world including Indian subcontinent (Dickins 1977, 1985; Dasgupta 2006) and the Karoo Basin, South Africa
(Von Brunn and Gravenor 1983; Visser 1997a). Eustatic sea-level rise associated with climate amelioration and enhanced rates of ice sheet melting were the main causes of this transgression (Dickins 1977, 1985; Wardlaw and Pogue 1995). Vertical and lateral facies changes from shallow marine to marginal marine within the Dandot Formation imply a significant basinward shift of environment and lowering of the sea-level (cf. Veevers and Tewari 1995; Fielding et al. 2006). A sudden change in lithofacies from marginal-shallow marine in the upper parts of the Dandot Formation to meandering fluvial in the Warchha Sandstone is an indication of forced regression. This regression was most probably related to an isostatic rebound associated with the late stages of deglaciation across the region (Haldorsen et al. 2001). The topographically-elevated areas of the Aravalli and Malani ranges to the south and southeast of the Salt Range region may have been raised at that time (Ghazi and Mountney 2011).

The second major sea-level change occurred during Late Artinskian to Early Kungurian time. The presence of trace fossils such as Helminthopsis and Skolithos, which are indicative of shallow and marginal marine conditions in sandy shoreline setting (Bjerstedt 1988), on the top surface of the Warchha Sandstone demonstrates a landward shift of the shoreline position (e.g., Bjerstedt 1988; Amireh et al. 2001; Fielding et al. 2006) and subsequent marine flooding across the uppermost Warchha Sandstone surface. At this time, the Tethyan Sea transgressed to form a broad embayment across much of the Salt Range area. The overlying Sardhai Formation was accumulated in this embayment as a shallow marine succession (Veevers and Tewari 1995; Wardlaw and Pogue 1995). The contact between the upper part of the Warchha Sandstone and the overlying Sardhai Formation is an unconformable and erosive wave ravinement surface, which was generated as the transgression proceeded across the area. This transition from fluvial-coastal to shallow marine sediments in the Salt Range is the principal evidence for a region-wide transgressive event associated with a significant rise in relative sea level. This second sea-level change can be related to eustatic sea-level rise and climatic change. As temperature increased, perhaps as the final phase of the Permian deglaciation occurred in the northern part of the Gondwanaland, so the final eustatic sea-level rise occurred (Shah and Sastry 1973). The direction of transgressions seems to have been almost perpendicular to present geographic position of the Salt Range (figure 7). Accumulation of the Nilawahan Group was terminated by a major marine transgression that occurred from Middle Permian through to Late Permian time (figures 2 and 3; 


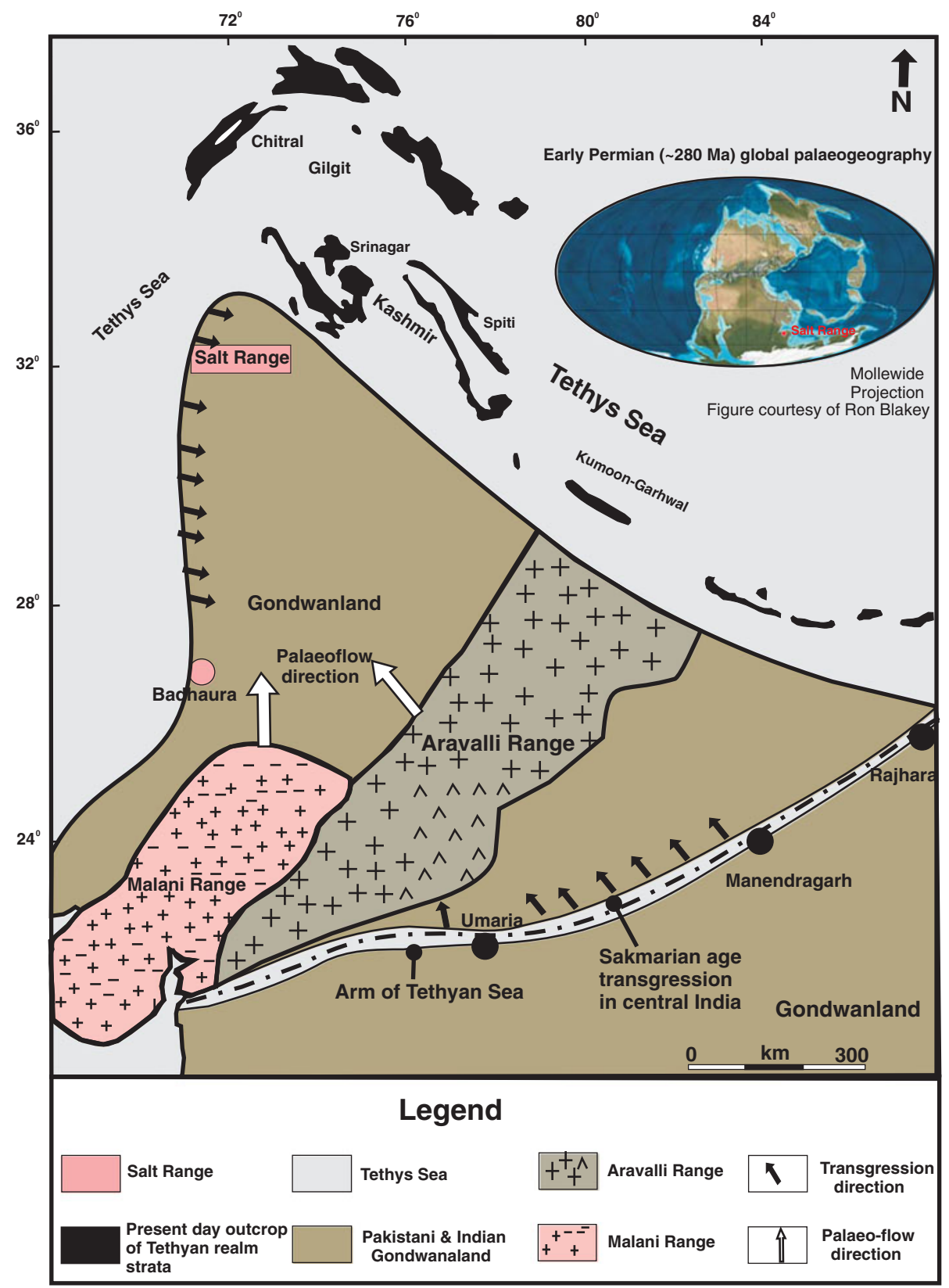

Figure 7. Palaeogeographic map (showing present day longitude and latitude) of the Pakistani and Indian parts of Gondwanaland during the Early Permian. The location of the Salt Range and main sediment source areas are shown (modified after Shah and Sastry 1973). During Permian times, the Pakistan region occupied part of Gondwanaland at a palaeolatitude of $50^{\circ}-55^{\circ}$ south of the equator and was bordered to the north by a large marine embayment that formed part of the Tethys Ocean.

Kummel and Teichert 1970; Gee 1989; Wardlaw and Pogue 1995; Mertmann 2000).

\section{Correlation with other Gondwana basins}

The Tobra Formation, which was previously known as the Talchir Boulder Bed (Noetling 1901) in Pakistan, and Talchir Formation, previously known as Talchir Group in India, can be correlated in terms of age, lithofacies stratigraphic position and faunal assemblages with the Dwyka Group of the Karoo Basin, South Africa. A major glacial episode is known to have occurred synchronously during Late Palaeozoic times in both continents. The Dandot Formation can be correlated with Eurydesmabearing Umaria marine beds, which overlie the Asselian age Talchir Formation in India (figure 5; cf. Shah and Sastry 1973). In the Manendragarh and Rajhrara areas of central India, these marine 
beds occur between the Talchir and Karharbari formations (cf. Shah and Sastry 1973). Ghosh and Basu (1967) suggested that Umaria marine beds and the Dandot Formation (Conularia Beds) are the marine equivalent of the basal Karharbari Formation of India. Therefore, in the areas where the marine beds are missing, the Dandot Formation is equivalent to the upper part of the Talchir and Karharbhai formations (figure 5). Similarly, based on stratigraphic position and biostratigraphic characteristics, the Dandot Formation can be related to the Late Sakmarian to Early Artinskian age shallow marine deposits of the Pebbley Beach Formation of the southern Sydney Basin in New South Wales, Australia (cf. Fielding et al. 2006). Waterhouse (1970) related the Dandot Formation to parts of the Permian sequence of Tasmania and Western Australia, which commences with tillite and is overlain by marine beds with abundant Eurydesma.

Based on lithological analogies and stratigraphic position, the Warchha Sandstone which overlies the Dandot Formation in the Salt Range is correlated to the Barakar Formation of India (cf. Casshyap and Tewari 1982). Both formations are characterised by a succession of several fluvial fining-upward cycles of sedimentation and both are interpreted to represent the preserved deposits of fluvial environment (figure 5). These two formations were deposited in a similar palaeoenvironmental setting but in two different basins which were separated by a high mountain chain (represented by the Aravalli Range) (Ghazi and Mountney 2011) at the time of accumulation. The absence of coalbearing deposits in the Warchha Sandstone and their presence in the Barakar Formation are most likely due to the different geographic locations of the two basins and their different prevailing palaeoclimates. Based on stratigraphic position and age, the Sardhai Formation of Salt Range (Kungurian) can be correlated to the Barren Measures Formation (Kungurian) of India and its equivalent, the Motur Formation, in the Satpura Basin of India. The Sardhai Formation overlies the Warchha Sandstone (Artinskian) in the Salt Range and the Barren Measures Formation overlies the Barakar Formation (Artinskian) in India (figure 5).

\section{Palaeoenvironmental implications}

As a north-western part of the Indian Peninsula, the Salt Range region occupied a palaeogeographic position that formed part of east Gondwanaland (Valdiya 1997). The basement rocks beneath the Salt Range are composed of Precambrian metamorphic and plutonic constituents of the northern extension of the Indian Shield. The Eocambrian
Salt Range Formation directly overlies crystalline basement rocks and is followed by a shallow marine sequence of the Cambrian age. After the Cambrian sequence, there was a pronounced interruption in basin filling in the Tethyan realm in the northern margin of the Indian Peninsula (cf. Gee 1989; Valdiya 1997). The whole of the Gondwanic India was evidently uplifted at this time in what is known as the Pan-African orogeny in Gondwanaland (Valdiya 1997). This basinal feature subsequently commenced filling with Gondwana sediments, initially with glacio-fluvial deposits of the Tobra Formation (the Talchir) in a cold climate (Singh 1987; Valdiya 1997). At this time, glaciers covered the Aravalli Range at least $600 \mathrm{~km}$ to the south and these extended northward to the Salt Range (figure 8). Teichert (1967) reported the occurrence of Asselian age boulder beds (Tobra Formation) about $500 \mathrm{~km}$ south of the Salt Range in the Badhaura area in Rajasthan, India (figure 7). Similarly, after detailed work on the clast composition, lithofacies pattern and palaeocurrent analysis on the Talchir Formation (a lateral equivalent to the Tobra Formation in India), it was concluded that direction of the ice movement in Talchir (Tobra) times was from south to north (Ahmad 1970; Sengupta 1970; Dasgupta 2006). This suggests that during Early Permian times drainage was from the Badhaura area in south to the Salt Range in north to northwest direction and palaeoslope would therefore have been towards north (cf. Krishnan 1960; Shah and Sastry 1973; Valdiya 1997). To the east and south of the Salt Range, the elevated area of the Aravalli Range likely formed eastern coastline limit of an extended sea (figure 7; cf. Shah and Sastry 1973).

The glaciers retreated as the climate ameliorated and sea levels rose, resulting in transgression across the basin, as recorded by the Dandot Formation (cf. Singh 1987; Veevers and Tewari 1995). The basement rocks were uplifted in the east of the Salt Range and a marked relative sea-level fall occurred, eventually culminating in sub-aerial exposure of the entire Salt Range area. Seasonally heavy rainfall in a hot and humid climate to the south helped to establish a major river system (as represented by the fluvial Warchha Sandstone), which flowed into the basin from the south-southeast and discharged into a marine embayment that lay to the north-northwest. The fluvial system of Warchha Sandstone is more thickly deposited in the western Salt Range than in the east. It is suggested that the Gondwana river channel, while maintaining an essentially northerly-flowing course, gradually shifted laterally to the west at this time, within its basin of deposition. The meandering Warchha river repeatedly shifted its position with time in its floodplain. 
The Salt Range being part of western Indian Peninsula had a north-northwest-directed drainage system during the Early Permian, and the Warchha river flowed from the Aravalli Range northwards to the Tethys Sea (figure 8), marine deposits of which are now to be found exposed in the foothills of the Himalayas (Valdiya 1997). However, overall the network of the north-northwesterly-flowing river systems ultimately discharged to the Tethys as demonstrated by the presence of marginal to shallow marine strata at the bottom and top of the Warchha Sandstone, and an overall north to north-westerly fluvial transport direction.

The depositional history of the Warchha Sandstone witnessed marginal uplift of the eastern Salt Range and down-wrapping. Episodic pulses of uplift of the eastern Salt Range during the middle Warchha Sandstone is indicated by the presence of sub-angular clasts of the limestone, sandstone and dolomite of the Cambrian sequence (Ghazi and
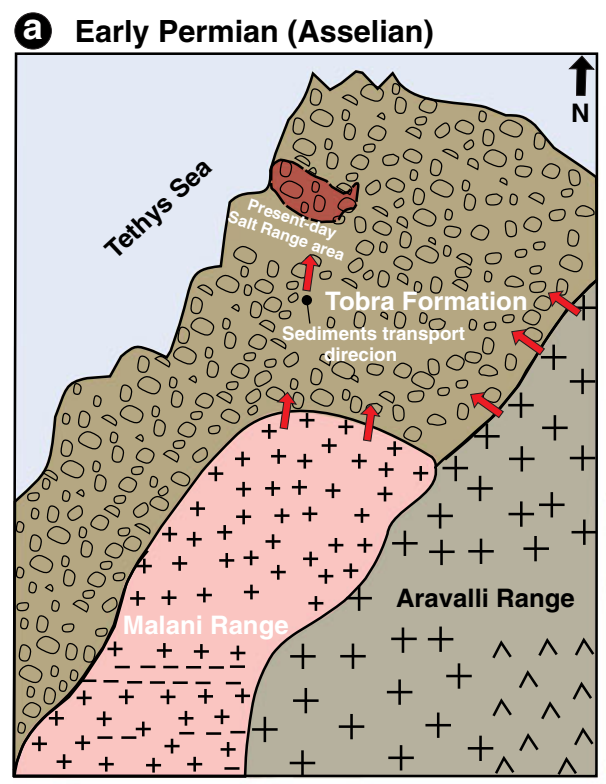

C Early Permian (Artinskian)

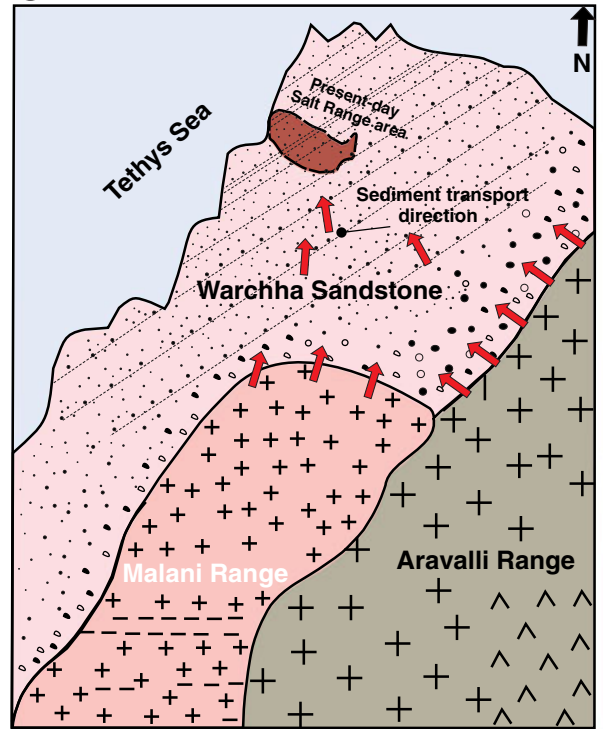

\section{(b) Early Permian (Sakmarian)}

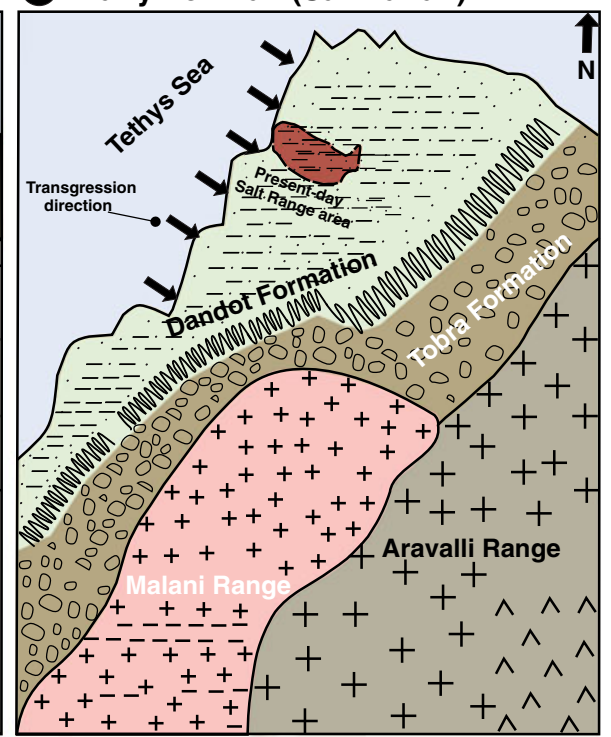

d Early Permian (Kungurian)

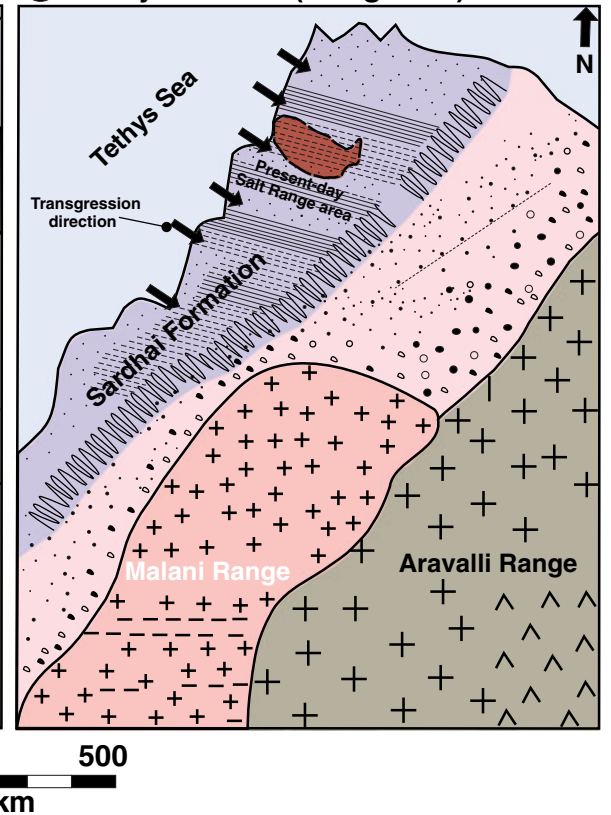

Figure 8. Tectono-stratigraphic evolution of the present-day Salt Range area through the Early Permian (a-d) Asselian to Kungurian times. These maps illustrate the change of sedimentation style from fluvio-glacial (Tobra Formation), to shallow to marginal marine (Dandot Formation), to meandering fluvial (Warchha Sandstone) and shallow marine (Sardhai Formation). 
Mountney 2011). The cessation of Warchha Sandstone sedimentation is marked by an abrupt termination of the fluvial meandering setting and its replacement with very shallow marine deposits of the overlying Sardhai Formation (figure 4). This second phase records a relative sea-level rise and is marked by a regional unconformable contact at the top of the Warchha Sandstone that is associated with wave ravinement during transgression. This phase is dated Artinskian to Kungurian age.

The drainage pattern remained essentially unchanged throughout the Early Permian time (figure 8), being directed dominantly from southsoutheast to north-northwest (Casshyap and Tewari 1982; Valdiya 1997). A major tectonic event can be recognised after the deposition of the Warchha Sandstone and overlying the Sardhai Formation, during which the whole Salt Range witnessed tectonism by uplift and subsidence. A sedimentary platform developed on Gondwana continental crust in front of Indian Shield and shallow marine carbonated deposits of the Tethyan regime (Zaluch Group) are unconformably overlying the clastic sediments of the Gondwanaland regime (Nilawahan Group) (Mertmann 2003). The stratigraphic relationship of the Early Permian rocks in the Salt Range indicates that the basin was opening and deepening towards north to northwest direction. The preferred palaeogeographic reconstruction therefore suggests that the marine incursion in the Salt Range came from this direction (figure 7).

\section{Conclusions}

The Early Permian sequence of the Nilawahan Group in the Salt Range of Pakistan provides a sedimentary record of a late glacial and postglacial episode in which a range of glacio-fluvial, marine and fluvial environments were developed. The Nilawahan Group records three major breaks in sediment accumulation: firstly at the base of the Tobra Formation, secondly between the Dandot and the Warchha formations, and thirdly at the top of the Sardhai Formation. During Late Carboniferous times the entire Gondwanaland landmass was covered by glaciers. As climate ameliorated, the glaciers commenced their retreat resulting in the deposition of the Tobra Formation during the Asselian. Clast provenance indicates that these glacial sediments were largely derived from the movement of ice sheets over and erosion of igneous and metamorphic basement rocks of the Aravalli and Malani ranges. A gradual rise in the sealevel through the latter phase of the Tobra Formation deposition culminated in the transition to the accumulation of marine sediments of the Dandot
Formation in the Sakmarian. The presence of fauna like Conularia and Eurydesma, together with a distinctive lithofacies characterised by a distinctive suite of sedimentary structures confirm the marine-marginal to marine origin of the Dandot Formation. The marine incursion represented by the Dandot Formation did not persist and a subsequent fall in relative sea-level is marked by the onset of fluviatile sedimentation of the Warchha Sandstone. By the end of the episode of Dandot sedimentation, climate amelioration had resulted in a change to cool-temperate conditions. Within the overlying Warchha Sandstone, the presence of granitic and metamorphic pebble-grade clasts within the otherwise fine- to medium-grained sandstone facies suggests their derivation mainly via the reworking of igneous and metamorphic rocks and their extended transport prior to deposition in distal parts of a major river course. The Warchha Sandstone in the Salt Range area records an episode of fluvial, coastal to estuarine conditions during the Artinskian. A gradual relative sea-level rise caused by further climatic warming and/or tectonic movement was responsible for a marine transgression over the top of the uppermost Warchha Sandstone surface and the onset of marine sedimentation of the Sardhai Formation.

\section{References}

Ahmad F 1970 Marine transgression in the Gondwana system of Peninsular India - a reappraisal; In: Proceedings of Second Gondwana Symposium (ed.) Haughton S H, South Africa, Pretoria, Council for Scientific and Industrial Res., pp. 179-188.

Alam G S, Mashhadi S T A and Khan M A 1987 Interim report on Permian coal exploration in Punjab Plains (drilling at Ashaba, district Jhang); Geol. Surv. Pakistan Information Release 286, p. 30.

Amireh B S, Schneider W and Abed A M 2001 Fluvialshallow marine-glaciofluvial depositional environment of the Ordovician System in Jordan; J. Asian Earth Sci. 19 45-60.

Angiolini L, Crasquin-Soleau S, Platel J P, Roger J, Vachard D, Vaslet D and Al-Husseini M 2004 Saiwan, Gharif and Khuff formations, Haushi-Huqf uplift, Oman; GeoArabia Spec. Publ. 3 149-183.

Balme B E 1970 Palynology of Permian and Triassic strata in the Salt Range and Surghar Range, West Pakistan; In: Stratigraphic Boundary Problems: Permian and Triassic of West Pakistan (eds) Kummel B and Teichert C, Univ. Kansas Spec. Publ. 4 305-453.

Bangert B, Stollhofen H, Lornez V and Armstrong R 1999 The geochronology and significance of ash-fall tuffs in the glaciogenic Carboniferous-Permian Dwyka Group of Namibia and South Africa; J. African Earth Sci. 29 33-49.

Bischoff J L, Fitzpatrick J A and Rosenbauer R J 1993 The solubility and stabilization of ikaite $\left(\mathrm{CaCO}_{3} \cdot 6 \mathrm{H}_{2} \mathrm{O}\right)$ from $0^{\circ}$ to $25^{\circ} \mathrm{C}$ : Environment and palaeoclimate implications for thinolite tufa; J. Geol. 101 21-33. 
Bjerstedt T W 1988 Trace fossils from the early Mississippian Price delta, southeast west Virginia; J. Paleontol. 62 506-519.

Blanford W T, Blanford H F and Theobald W 1856 On the geological structure and relations of the Talcheer coalfield in the district of Cuttack; Geol. Surv. India Memoir 1 $1-98$.

Butt K A, Islam U Z, Chaudhary M I and Khan J A 1994 Discovery of Early Permian carbonatitic to melilititic/Nephelinitic glassy flows in eastern Salt Range, Pakistan; Kash. J. Geol. 4 33-50.

Casshyap S M and Tewari R C 1982 Facies analysis and Palaeogeographic implications of a Late Palaeozoic glacial outwash deposit, Bihar, India; J. Sedim. Petrol. 52 1243-1256.

Collinson J D, Mountney N and Thompson D B 2006 Sedimentary structures; Terra Publisher Hertfordshire, England, 292p.

Dasgupta P 2006 Facies characteristic of Talchir Formation, Jharia Basin, India: Implications for initiation of Gondwana sedimentation; Sedim. Geol. 185 59-78.

Dickins J M 1977 Permian Gondwana climate; Chayanica Geology 3 11-22.

Dickins J M 1985 Late Palaeozoic glaciation; J. Bur. Min. Resour. Austr. Geol. Geophys. 9 163-169.

Fatmi A N 1973 Lithostratigraphic units of the KohatPotwar Province, Indus Basin; Geol. Surv. Pakistan Memoir 10, 80p.

Fielding C R, Bann K L, Maceachern J A, Tye S C and Johns B G 2006 Cyclicity in the near-shore marine to coastal. Lower Permian, Pebbley Beach Formation, southern Sydney Basin, Australia: A record of relative sea-level fluctuations at the close of the of the Late Palaeozoic Gondwanan ice age; Sedimentology 53 435-463.

Gee E R 1980 Pakistan Salt Range series geological maps, 1: 50,000, 6 sheets; Geol. Surv. Pakistan.

Gee E R 1989 Overview of the geology and structure of the Salt Range with observations on related areas of northern Pakistan; Geol. Soc. Am. Spec. Publ. 232 95-112.

Ghazi S 2005 Fluvial fining upward cycles of the Lower Permian Warchha Sandstone, Salt Range, Pakistan; Abstract volume, 8th International Fluvial Sedimentological Conference Delft, Holland, p. 109.

Ghazi S 2009 Sedimentology and stratigraphic evolution of the Early Permian Warchha Sandstone, Salt Range, Pakistan; Unpublished Ph.D thesis (University of the Leeds, England), p. 362.

Ghazi S and Mountney N P 2009 Facies and architectural element analysis of a meandering fluvial succession: The Permian Warchha Sandstone, Salt Range, Pakistan; Sedim. Geol. 221 99-126.

Ghazi S and Mountney N P 2011 Petrography and provenance of the Early Permian Fluvial Warchha Sandstone, Salt Range, Pakistan; Sedim. Geol. 233 88-110.

Ghazi S, Butt M J, Shahzad A and Hussany U 2004 Palaeocurrent analysis of the Lower Permian Warchha Sandstone, Karuli Village, central Salt Range, Pakistan; Pun. Univ. J. Env. Earth Sci. 1-2 64-85.

Ghosh P K and Basu A 1967 Stratigraphic position of the Karharbaris in the lower Gondwana of India; In: Gondwana stratigraphy, International Union of Geological Sciences (IUGS) Symposium, Buenos Aires, pp. 407-419.

Ghosh P K and Mitra N D 1970 Sedimentary framework of glacial and periglacial deposits of the Talchir Formation of India; In: Proceedings of Second Gondwana Symposium (ed.) Haughton S H, South Africa, Pretoria, Council for Scientific and Industrial Research, pp. 213-224.
Gradstein F M, Ogg J G and Smith A G 2004 A geological time scale; Cambridge University Press, United Kingdom, p. 589.

Haldorsen S, Von Brunn V, Maud R and Truter E D 2001 A Weichselian deglaciation model applied to the Early Permian glaciation in the northeast Karoo Basin, South Africa; J. Quat. Sci. 16 583-593.

Hussain B R 1967 Saiduwali Member, a new name for the lower part for the Permian Amb Formation, West Pakistan; Karachi Univ. Studies Sci. \& Tech. 4 88-95.

Krishnan M S 1960 Geology of India and Burma; Higgin Brothers Ltd., Madras, 604p.

Kummel B and Teichert C 1970 Stratigraphy and palaeontology of the Permian-Triassic boundary beds, Salt Range and Trans Indus Ranges, West Pakistan; In: Stratigraphic Boundary Problems: Permian and Triassic of West Pakistan (eds) Kummel B and Teichert C, Univ. Kansas Spec. Publ. 4 1-110.

Lillie R J, Johnson G D, Yousuf M, Zaman A S H and Yeats R S 1987 Structural development within the Himalayan foreland fold-and-thrust belt of Pakistan; In: Sedimentary Basins and Basin-Forming Mechanisms (eds) Beaumont C and Tankard A J, Can. Soc. Petro Geol. Memoir 12 379-392.

Mertmann D 2000 Foraminiferal assemblages in Permian carbonates of the Zaluch Group (Salt Range and the Trans-Indus Range, Pakistan). Neues Jahrbuch für; Geologie und Paläontologie Mh 3 129-146.

Mertmann D 2003 Evolution of the marine Permian carbonate platform in the Salt Range (Pakistan); Palaeogeogr. Palaeoclimatol. Palaeoecol. 191 373-384.

Mukhopadhyay G, Mukhopadhyay S K, Roychowdhury M and Pauri P K 2010 Stratigraphic correlation between different Gondwana Basins of India; J. Geol. Soc. India 76 251-266.

Noetling P 1901 Beitrage zur Geologie der Salt Range, insbesondere der permichen und triasuchen Ablagerungen; Neues Jahrbuch Mineralogie Beilage Beilageband 14 369-471.

Pascoe E S 1959 A Manual of the Geology of India and Burma; Government of India Press, Calcutta 2 385-1343.

Qureshi M K A 1980 Copper showing in Warchha Sandstone and Sardhai Formation, Salt Range; Contrib. Geol. Pakistan, pp. 61-87.

Ranger M J and Pemberton S G 1997 Elements of stratigraphic framework; In: Petroleum Geology of the Cretaceous Mannville Group (eds) Pemberton S G and James D P, Can. Soc. Petrol. Geol. Memoir 18 263-291.

Reed F R C 1944 Brachiopoda and Mollusca from the Productus Limestone of the Salt Range; Pal. Indica (NS) 23 $1-65$.

Sengupta S 1970 Gondwana sedimentation around Bheemaram (Bhimaram) Pranhtia-Godavari Valley, India; J. Sedim. Petrol. 40 140-170.

Shah S M I 1977 Stratigraphy of Pakistan; Geol. Surv. Pakistan Memoir 12138.

Shah S C and Sastry M V A 1973 Significance of Early Permian marine Faunas of Peninsular India; In: Proceedings of Third Gondwana Symposium (ed.) Campbell K S, Canberra, Australia, pp. 391-395.

Singh T 1987 Permian biogeography of the Indian subcontinent with special reference to marine fauna; In: Geophysical monograph, stratigraphy, sedimentology and palaeontology (ed.) McKenzie G D, Gondwana six, American Geophysical Union, 41 239-249.

Stow D A V 2005 Sedimentary rocks in the field; Manson Publ. Ltd., London, 320p.

Teichert C 1967 Nature of Permian glacial record, Salt Range and Khisor Range, West Pakistan: Neues Jahrbuch 
fr; Geologie und Paläontologie. Abhandlungen 129 167-184.

Valdiya K S 1997 Himalaya, the northern frontier of East Gondwanaland; Gondwana Res. 1 2-9.

Veevers J J and Tewari R C 1995 Gondwana Master Basin of Peninsular India between Tethys and the interior of the Gondwanaland Province of Pangea; Geol. Soc. Am. Memoir 187, p. 72 .

Visser J N J 1997a Deglaciation sequences in the PermoCarboniferous Karoo and Kalahari basins of southern Africa: A tool in the analysis of cyclic glaciomarine basin fill; Sedimentology 44 507-521.

Visser J N J 1997b A review of the Permo-Carboniferous glaciation in Africa; In: Late Glacial and Postglacial Environment Changes (ed.) Martini J B (New York, Oxford Univ. Press), pp. 169-191.

Von Brunn V and Gravenor C P 1983 A model for late Dwyka glaciomarine sedimentation in the eastern Karoo Basin; Trans. Geol. Soc. South Africa 86 199-209.
Waagen W 1878 Salt Range fossils, Productus Limestone Group; Geol. Surv. India Paleontol. Indica Ser. 13(1-7) 998.

Waagen W 1883 Salt Range fossils, Productus Limestone Fossils IV, Brachiopoda; Palaon. Indica Ser. 13(1) 2.

Wardlaw B R and Pogue K R 1995 The Permian of Pakistan; In: The Permian of Northern Pangea, 2. Sedimentary Basins and Economical Resources (eds) Scholle $\mathrm{P}$ A, Peryt T M and Ulmer-Scholle D S (New York: Springer Verlag), pp. 215-224.

Waterhouse J B 1970 Correlation of marine Permian Faunas for Gondwana; In: Proceedings of Second Gondwana Symposium (ed.) Haughton S H, South Africa, Pretoria, Council for Scientific and Industrial Res., pp. 381-394.

Wensink H 1975 The palaeo-magnetism of the speckled sandstone of Early Permian age from the Salt Range, Pakistan; Tectonophys. 26 281-292.

Wynne A B 1878 On the geology of the Salt Range in the Punjab; Geol. Surv. India Memoir 14 1-309.

MS received 22 February 2012; revised 3 May 2012; accepted 16 May 2012 